\title{
Transforming Passive Listeners into Active Speakers: A Study with Portuguese Undergraduates in 'English for the Social Sciences'
}

\author{
Rita M. Amorim ${ }^{1}$ \\ ${ }^{1}$ CAPP, ISCSP- Technical University of Lisbon, Portugal \\ Correspondence: Rita Maria Amorim, Rua Presidente Arriaga, N.2 - 1ª 1200-772 Lisboa, Portugal. Tel: \\ 351-917-247-744. E-mail: ramorim@iscsp.utl.pt
}

Received: February 13, 2013 Accepted: March 11, 2013 Online Published: March 20, 2013

doi:10.5539/elt.v6n4p110 URL: http://dx.doi.org/10.5539/elt.v6n4p110

\begin{abstract}
In the present context of English as a Lingua Franca (ELF) or English as International Language (EIL), it has become extremely relevant to maximize speaking opportunities in the English as a Foreign Language (EFL) classroom which aim at developing fluency and real-life communication skills. University students in Portugal need to practice expressing their views and sharing opinions in English for their professional careers and for general international communication. With these aims in mind, 'whole-class discussions' were implemented in the subject 'English for the Social Sciences', but monitoring by the teacher revealed low voluntary participation. This classroom-based study began with two questionnaires distributed to a group of twenty intermediate to upper-intermediate undergraduates. They exposed speaking anxiety due to worries about producing accurate English, fear of poor performance and negative evaluation, and embarrassment to speak in front of colleagues. A two-step strategy was implemented to get as many students as possible speaking, by overcoming some of their linguistic and personality barriers. First, students attended two awareness-raising lessons on the aims of whole-class activities, the value of fluency, and today's real-life communicative skills. Then, small 'buzz-group' discussions were implemented, prior to and in preparation of the 'whole-class discussions' to create a more supportive environment. Student interviews and teacher observation notes were used to collect participants' perspectives. Findings revealed that passive listeners, when better informed and working in a less anxiety-inducing environment, can become active speakers.
\end{abstract}

Keywords: English as a Lingua Franca (EFL), English as a Foreign Language (ELF), English as International Language (EIL), fluency, communicative skills, speaking anxiety, motivation

\section{Introduction}

EFL teachers have always been concerned with promoting speaking inside the classroom, and trying to approximate it to real-life communication (Nunan, 1998). Maximising speaking opportunities sometimes is not enough and low participation is encountered. Speaking anxiety can render some students unable to develop their oral performance, becoming passive speakers.

The role of ELF in the $21^{\text {st }}$ Century has made it more relevant for EFL teachers to try and help students acquire fluency and develop communicative skills that they can use outside the classroom. Nowadays, most interactions in English take place between people of different mother tongues, for whom English is the international means of communication. Many scholars as Graddol $(1997,2006)$ have acknowledged that non-native speakers of English have outgrown native-speakers in a very different English-speaking world. The Expanding Circle first described by Kachru in 1985 is now described as a context of 'English-knowing' citizens of different proficiencies who use English as their functional contact language (Graddol, 2006). There is also a growing tendency for the EFL group of speakers who traditionally used English for contact with native speakers to become speakers who use the language for intercultural contact amongst themselves (Jenkins, 2009). Europeans are clearly included in this group of users.

Similarly to what happens in some Northern European countries, there are universities in Portugal that offer higher education in English. In others, English is a compulsory subject whose objective is to realistically prepare students to communicate efficiently and intelligibly in EIL. It seems therefore relevant for EFL professionals working in these contexts to aim at promoting learners' speaking competence with an emphasis on fluency. University students in Portugal are encouraged to participate in communicative activities to express their views 
and share opinions on issues related to their field of studies. These activities are designed to improve target language fluency (Harmer, 2001). The aim is to give students practice in speaking naturally and genuinely, a useful tool outside the classroom. Learners need to process language for communication (Harmer, 2001), getting the message across, understanding and being understood in internationally acceptable English (Ur, 2009). 'Whole-class discussions' are implemented to foster communication among a fairly large number of students. These activities may be more appropriate for higher level students because they can learn to express themselves fluently and spontaneously through long episodes of 'self-generated discourse' (Murphy 1991; Harmer 2001) . Teachers may implement them to induce learners to talk and use language creatively, purposefully and individually Ur (1981). Successful speaking activities are those where learners talk a lot, participation is even, motivation is high and language is of an acceptable level (Ur, 1991:120). A continuing complex matter for EFL practitioners is that these learning objectives may be prevented if students experience speaking anxiety, a general broad term which may include: target or foreign language anxiety, classroom anxiety (Brown \&Yule, 1983: Brown, 2000), state anxiety, trait anxiety, evaluation anxiety, task anxiety.

It is hypothesized that students can participate more when there is a low-anxiety learning environment. This can be enhanced by awareness of the aim of fluency and communicative skills. The study will provide empirical evidence to confirm the hypothesis.

The present classroom-based study focuses first on exposing the linguistic and personality barriers preventing participation in 'whole-class discussions'. The main aim is to get as many students as possible participating, by implementing a two-step strategy to minimise the negative effects of speaking anxiety and raising motivation to speak. As a qualitative study, the findings are based on the perspectives of the participants collected by means of teacher observation notes and student interviews.

\section{Review of Literature}

\subsection{Language is Communication, in and out the Classroom}

One of the most relevant common features of our multicultural, multilingual globalized world is English in it new global form (Graddol, 2006). English has been differently named as World English, International English, or Global English. More recently, there has been a lot of research on English as a Lingua Franca (Dewey, 2007; Gnutmann and Intermann, 2005; Knapp and Meierkord, 2002; Jenkins, 2006a, 2006b, 2007; Seidlhofer, 2001, 2004). According to Seidlhofer (2005), today's non-native speakers are as much responsible for shaping English as are native speakers and the way they actually use it and make it work may have some implications for teaching. In this global context, speakers of EIL have developed specific skills of cooperation; collaboration; accommodation; and simplification, as each interaction demands adaptation to a different context, participant and purpose (Dewey, 2007; House, 2003; Hulmbauer, Bohringer, \& Seidlhofer, 2008; Jenkins, 2006a; Seidlhofer, 2001).

Though prescriptive directions do not yet exist as to the implications of EIL for EFL classrooms, emphasising fluency and raising learners' awareness to real-life communicative skills, may be a good place to start closing 'the conceptual gap' (Seidlhofer, 2001). This is all the more relevant because most non-native speakers in the real world no longer aim at native speaker proficiency or accuracy. It does not seem reasonable or useful to continue judging classroom spoken performance of EFL students negatively against native speaker competence and models, (Canagarajah, 2007; Dewey, 2007; House, 2003; Jenkins, 2006a, 2006b; Seidlhofer, 2001, 2002, and Seidlhofer \& Jenkins, 2003). When the aim is practising communication, the native speaker 'yardstick' (Jenkins, 2006a) seems inappropriate. Regardless of the emphasis teachers continue to place on accuracy in grammar input classes, EFL learners do not aim at becoming mother tongue imitators.

The growing tendency for English speakers in Europe to use the language for intercultural contact or interactions amongst themselves (Jenkins, 2009), has meant that most students want to become English-knowing competent language users who can function efficiently worldwide. Jenkins (2006a) claims that TESOL professionals are increasingly interested in the way English has been spreading and is currently being used. It is believed that EFL learners may also benefit from knowledge of the reality of the spread and use of the language, as it is their wish to understand and be understood in real-life situations, one of the most important tools of twenty-first century.

\subsection{Spoken Performance}

Human beings' ability to interact with one or more speakers for transactional and interactional purposes (Nunan, 1989 ) is quite a simple matter in the native language, but quite difficult in a foreign language. In the past, studies have dealt with spoken performance in the EFL classroom as it is a complex issue for both students and teachers (Brown \& Yule, 1983). Teachers recognize the usefulness of giving language learners as many opportunities to 
speak as possible (Harmer, 2001; Nunan, 1989; Ur, 1991). In fact, essential conditions for learning a language are exposure to input, use of language, and motivation to use it (Willis, 1996:11). Successful language learning needs 'realistic language use' in the classroom (Harmer, 2001) and encouragement to use spontaneous language forms (Brown \& Yule, 1983:2). By using long stretches of self-generated discourse students may express themselves fluently and spontaneously (Murphy, 1991:60).

Interaction in a foreign language demands performance of short and long turns (Brown \& Yule, 1983), managing interactions and topic changes, beginning and ending conversations, knowing when and how to take the floor, and negotiation of meaning (Nunan, 1989). Teachers promote speaking activities in the classroom to encourage students to talk and to promote speaking that may resemble real-life communication, as proximate as possible to genuine communication (Nunan, 1988:78). According to Nunan \&Lamb (1996:88), it is by speaking that learners learn to speak. Whole-class discussions are better suited for more advanced and for academic students (Ur, 1991) to achieve these skills.

\subsection{Speaking Anxiety}

Creating more opportunities to use language spontaneously and purposefully may encourage speaking. However, linguistic and non-linguistic reasons frequently prevent learners from wilfully engaging in communication. For this reason, speaking anxiety has been discussed by several scholars and practitioners (Brown, 2000 Bailey; Nunan, 1996). Anxiety is not an easy concept to define. When speaking in front of peers and teachers, students may experience fear of exposure, failure and negative evaluation, frustration, worry, uneasiness, self-doubt, inhibition, reticence and shyness, and embarrassment to speak in front of peers. These are, most of the times, worries about making mistakes, being fearful of criticism or losing face, or simply being shy of the attention that their speech attracts (Ur, 1991:121). According to Ellis (1986), the degree of anxiety that learners experience can be influenced by such affective factors as their personality, 'affect' being that which refers to emotion or feeling (Brown, 2000). Oral communication is a complex process (Murphy, 1991:51), and for many students, the exposure that classroom oral production requests is especially 'anxiety-inducing' (Bailey \& Nunan, 1996). Foreign language anxiety is said to affect the learning process negatively, while self-esteem, one's belief in one's performance and success, may enhance learning. It is defended that in communicative activities, management of classroom environment should be handled so that learners feel as comfortable and fear-free as possible to develop their self-confidence and motivation.

\subsection{Motivation}

Students need motivation to use the target language as often as possible, to be able to benefit from it (Willis, 1996) as motivation can result from learning as well as cause it (Ellis, 1986:76). To motivate students and make them more confident communicators, teachers should create a low-anxiety classroom with a more supportive environment to improve situational and task 'self-esteem' (Brown, 2000). There is a strong correlation between motivation and learning success (Dornyei, 1998; Harmer, 2001). It is important that learners hold the wish to speak fluently and naturally, as motivation is the "internal drive which pushes someone to do things in order to achieve something" (Harmer, 2001:51) and unmotivated students won't learn (Nunan \& Lamb, 1996:208). It seems relevant to claim that in the case of speaking activities, worrying less about accuracy, failure, and being judged by peers and teacher, may enhance intrinsic and extrinsic motivation to the point of success. Integrative motivation (Ellis, 1994), could in the case of EFL learners correspond to the wish to identify and communicate with other EIL users. The amount of effort learners are willing to put into a task, their attitude, may also gain from a cooperative environment where students are not judged, where they feel they make a contribution, and where the learning context is less stressful (Dornyei, 2001:130). Finding ways to enhance motivation and decrease anxiety to facilitate learning should be a constant challenge to teachers (Nunan 1996) as it is one of the most powerful influences on learning (Williams \& Burden 1997).

\section{Research Design}

This study could be said to follow an action research cycle as it included observation, identification of a problem, data gathering, suggestion of practical action, action design and implementation, monitoring and analysis of results, and original problem solved (Ur, 1991:329). Classroom research is a collaborative enterprise between researcher, teacher, and learner (Bailey \& Nunan, 1996). In the present study, students were constantly informed of the findings, reforms and results of the research in which they were active participants. The teacher was also the researcher, whose observation notes were one of the two research tools. The present research began with teacher's close monitoring of apparently successful topic-based 'whole-class discussions'. This exposed low participation and always by the same four or five students. If "a discussion that works is primarily one in which as many students as possible say as much as possible" (Ur, 1981:3) then the problem was identified. 


\subsection{Setting and Participants}

A total of 20 undergraduate students (one class) participated in this study from October until May. The voluntary participants were all Portuguese students of International Relations, of both sexes and of approximately the same age (18 to 20). The study took place in a Social Sciences' university in Lisbon, where 'English for the Social Sciences' is a compulsory subject. The language level of the participants was Intermediate/Upper Intermediate, and they formed a fairly homogenous group. One of the aims of the syllabus was for students to develop communicative competence on issues related to their field of studies to prepare for professional work in target discourse communities. 'Whole-class discussions' were regularly promoted to maximise such speaking opportunities.

\subsection{Preliminary Investigation}

Two anonymous questionnaires, whose general aim was to uncover why capable learners were unwilling to speak, were answered by the 20 participants during class time. Questionnaires were used because they are easy to distribute and collect and they do not take up a lot of class time as students all answer at the same time (Altricher, Posch, \& Somekh, 1993). As questionnaires are individual and confidential, it was believed there would be less pressure and more truthful results. Both questionnaires had closed-ended questions and students could choose more than one item in each group. Questionnaire A- 'Learning Needs and Preferences' (adapted from Nunan, 1988:50), was distributed first, to uncover students' likes and dislikes in the study of English. It took the students 5 minutes to answer the questionnaire and all of them chose more than one communicative situation, skill, learning activity and learning environment. In view of the findings that students wish to speak but are not comfortable in whole-class discussions, the teacher devised Questionnaire B- 'Speaking in whole-class discussions' which was distributed the following lesson to reveal the linguistic and non-linguistic reasons behind the low participation. The students took 10 minutes to answer this questionnaire, and all chose various linguistic and personality items. Findings led to the implementation of a two-step strategy to overcome the identified problem, speaking anxiety was inhibiting participation.

\subsection{Preliminary Findings}

3.3.1 'Questionnaire A- Learning Needs and Preferences'

Table 1. Students' answers in percentage numbers

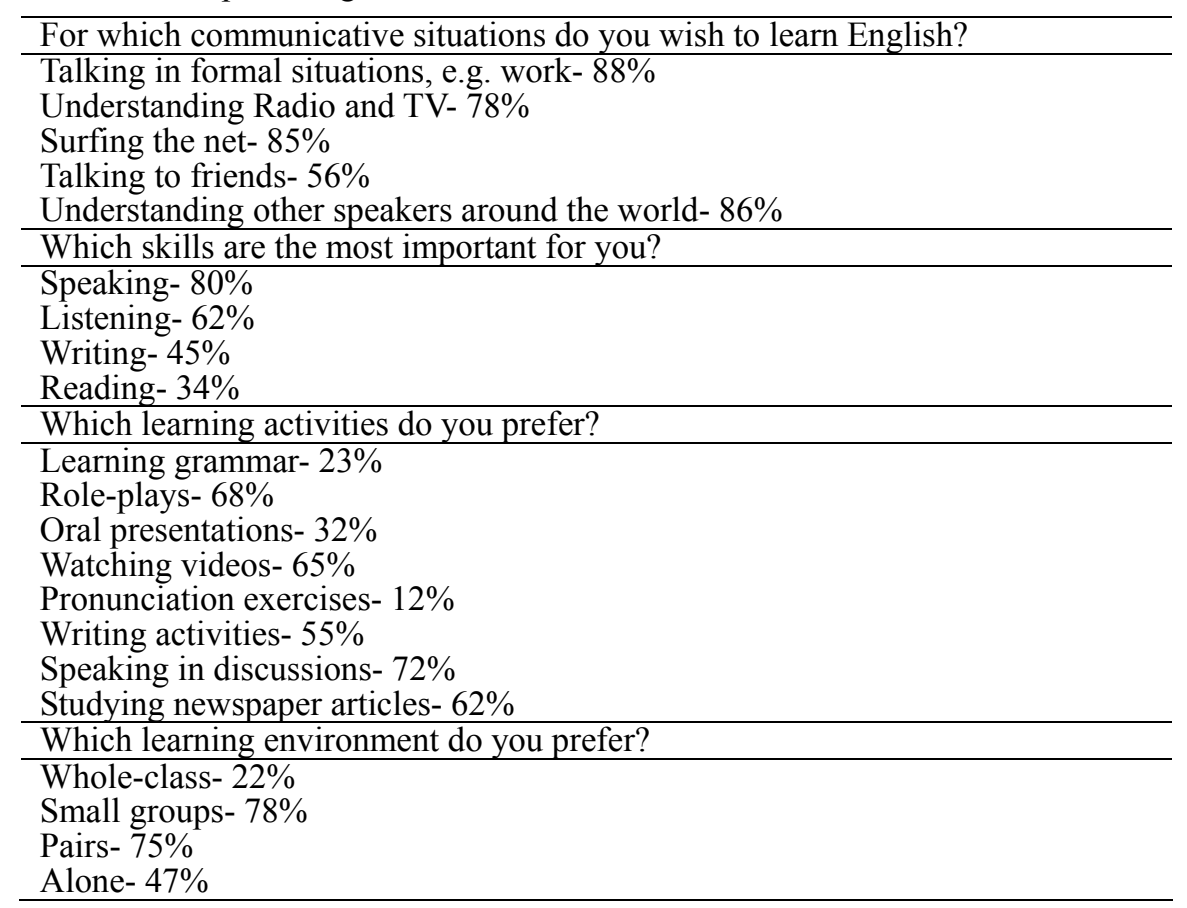

As shown in Table 1, there is the need and wish to speak and to use English functionally. 'Speaking' is the most important skill and 'Participating in discussions', the preferred learning activity. In relation to the learning environment, 'Small-groups' was the most chosen, and 'Whole-class', the least chosen. 


\subsubsection{Questionnaire B-'Speaking in Whole-Class Discussions'}

Table 2. Students' answers in percentage numbers

\begin{tabular}{l}
\hline During whole-class discussions: \\
\hline Linguistic Reasons \\
\hline I lack confidence in my spoken English- $67 \%$ \\
I am embarrassed to speak English- $58 \%$ \\
I am not used to speaking English in front of other people- $62 \%$ \\
I am afraid of making mistakes- $68 \%$ \\
I feel intimidated by stronger colleagues- $52 \%$ \\
I fear negative evaluation by the teacher- $70 \%$ \\
I do not believe my English can improve- $0 \%$ \\
\hline Personality Reasons \\
\hline I am embarrassed to speak in front of a lot of people- $6 \%$ \\
I am shy and prefer to listen to others- $55 \%$ \\
I lack confidence in myself to participate in such activities- $63 \%$ \\
I am afraid of not being successful- $72 \%$ \\
I do not like the topics of the Social Sciences- $0 \%$ \\
I do not like to share my view or give my opinion- $0 \%$ \\
I do not feel comfortable or at ease in this class- $0 \%$ \\
\hline
\end{tabular}

As shown in Table 2, students felt comfortable in this class and enjoyed the topics discussed. They enjoyed sharing views and giving opinions and believed their language competence could improve. It seems that low participation was caused by a mismatch between the desire to speak and the dislike of large audiences, and focusing on accuracy. Worries about performing inaccurately, producing proficient English and fear of failure caused anxiety and lack of motivation to speak. Generally speaking, EFL students are not aware that when performing a complete sentence in spoken language, it need not be perfectly correct (Brown \& Yule, 1983:26). They are unaware that L2 learning may involve risk taking and that their attitude is of extreme importance in controlling anxiety as learners with 'high self-efficacy' may sometimes perform better than more proficient colleagues (Williams and Burden, 1997:129). It seems vital to attempt active participation, free of native-speaker comparisons that results in fluency and intelligibility, as this is what learners need for real-life situations.

\subsection{A Two-Step Strategy}

\subsubsection{Step One- Awareness-Raising Lessons}

Students were informed of the results and implications of the questionnaires as this could help them prepare and be more willing to participate (Johnson, 1995). Bearing in mind that it is important for teachers to call learners' attention to the purpose of the activity, its potential interest and practical value (Dornyei, 1994), the first step of this research was to have the 20 students attend two awareness-raising lessons set up by the teacher. Lesson One intended to clarify the aims of whole-class discussions with an emphasis on the relevance of fluency (Dornyei, 1994; Brown \& Yule, 1983). Lesson Two was designed to raise learners' awareness to the characteristics of real international English; the communicative skills needed for real-life international communication, the more relevant communicative skills to acquire today; and the need to accommodate to different speakers, contexts and purposes, as referred by recent research on EIL (Dewey, 2007; House, 2003; Jenkins, 2003, 2006a, 2006b; Seidlhofer, 2001, 2002, Seidlhofer \& Jenkins, 2003; Ur, 2009).

\section{Lesson One}

Aims of whole-class discussions:

-Maximise speaking opportunities

-Share opinions and views

-Aim at fluency, getting the message across and being understood

-Objective is not native-speaker competence or imitation

-Emphasis on appropriateness, not correctness

-Engage in free, natural, uncontrolled interaction 
-Experiment acquired lexis or language

-Open-ended discussions, no right or wrong answers

-No evaluation, mistakes are not valued

-Manage turns and hold the floor, and keep the flow of conversation

Lesson Two

The English spoken by the majority nowadays:

-An intermediary, contact language for speakers of different L1s

-An instrumental, functional language

-A shared resource with great deal of variation but enough stability as lingua franca

The majority of its speakers in the Expanding Circle:

-Share a multilingual communicative competence and life

-Language users performing socio-pragmatic functions

-Do not aim at linguistic perfection or native-like performance

-Develop intercultural competence to adapt to intercultural communication

Descriptive characteristics:

-Unpredictability, variability, uniqueness, realness

-Certain features as phrasal verbs are not essential

-Typical errors as lack of $3^{\text {rd }}$ person $-\mathrm{s}$ are unproblematic

-Code switching is natural and L1 accent is preserved

-NNS performance not measured against NS

Communicative skills to help function internationally:

-Flexibility and adaptability to different contexts, participants and purposes

-Negotiation, collaboration, simplification

-Mutual accommodation- shorter utterances, reduced repertoire of tokens

-Overcome misunderstandings by repetition, topic change, rephrasing.

\subsubsection{Step Two- Small ‘Buzz-Group' Discussions}

The ground was now prepared for the second step, small 'buzz-group' (Harmer, 2001) discussions which preceded 'whole-class discussions'. 'Buzz groups' are a way of helping students who are reluctant to give their opinion in front of a whole class because they are not confident in their language ability or feel too exposed. Research has found that different activity types in small groups may promote interactive language use (Nunan, 1989: Harmer, 2001) because these are less intimidating (Murphy, 1991) and there is less risk of public failure (Harmer, 2001). Dornyei (1994:279) believes cooperative situations, small groups with members sharing responsibility, and a caring, cohesive relationship with others are "more powerful in promoting intrinsic motivation (in that it leads to less anxiety, greater risk involvement, and a more positive emotional tone)". Thus, this preparatory activity aimed at lowering the language and personality barriers identified in Questionnaire B. Getting students to participate first in a smaller, less threatening speaking environment, releases shyness and lowers the inhibitions of learners (Ur, 1991).

This strategy of pre-activity followed by real task took place once a month. There was a registered minimum presence of 17 students in each of the ten 90 minute-lessons. The given Social Sciences' topic was discussed first in groups of three or four which changed every time to ensure mixed-ability and variety of speakers. The groups were allowed 20 minutes and then were geared into the normal seating arrangement for the whole-class discussion of the same topic which lasted until the end of the lesson. At first, this procedure was difficult as students continued talking with their group members, but they gradually became more comfortable with the management of the activities.

\subsection{Voices from the Classroom}

As a qualitative classroom-based research, the focus is on hearing insiders' voices. Two research tools were used to collect all the participants' perspectives and provide a more complete picture: 


\subsubsection{Teacher Observation Notes}

The teacher adopted the role of researcher inside her own classroom as colleagues were not available due to lesson overlaps. The positive aspect was that learners felt at ease as there was no 'outsider'. On the other hand, it was not always easy to personify the researcher when students only saw their teacher. With time, monitoring and taking down notes improved. The total amount of participations, the names of participants, the number of participations per student, and the average length of turns were registered in each discussion lesson. These observation notes were analysed at the end of the ten discussion lessons. Teachers' tolerance of error in fluency sessions is greater (Harmer, 2001). No correction occurred during the group or class discussions. A record of more serious language errors was kept for accuracy work carried out in the grammar lessons.

\subsubsection{Student Interviews}

At the end of the year, the teacher carried out an individual interview with each of the twenty students. These lasted for five minutes, and were recorded and transcribed for analysis. Although this is a very time-consuming process, it was considered the best option since there were only 20 students and it was relevant to hear their voices and catch their feelings. For the same reason, participants were asked one open-ended question: How have 'whole-class discussions' changed for you? This frequently led interviewer and interviewee to engage in a dialogue. Some samples were selected (see Appendix-Excerpt commentaries).

\section{Findings}

\subsection{Teacher Observation Notes}

Before the study was implemented with this group of twenty students, teacher encountered an uneven distribution of talk in whole-class discussions. There were four or five very participative students who dominated each discussion and an additional five or six who participated occasionally. More or less $50 \%$ of the students never spoke. At the end of the study, all students had participated in at least four of ten whole-class discussions. There was a gradual but steady increase in participants, and new voices being heard for the first time. The greatest increase was in the number of irregular participants, those who only participated sometimes. Fourteen students had a more regular and assertive participation, attempting second and third turns, even when first turn received an opposing comment. On the whole, there were longer turns and several unfinished turns inviting others to join. Lots of typical speech markers as whuh, erm, oh, um, am, expressions as well, I think, you know, pauses, code switching, and overlapping talk suggest spontaneity and naturalness in communication. There was a fairer distribution of speaking time among all students, with less opportunity for the more dominating students to fill in for the silence of more passive ones. Gradually, interaction was less and less directed at teacher, and more at the common audience, suggesting that students were less concerned about inaccurate performance, mistakes or evaluation. Students sometimes took the discussions to other related issues revealing greater involvement and motivation. They managed topic switches, an important communicative skill. Social sciences lexis was previously 'tried out in the small groups. On the whole, this does not seem to have affected naturalness and may have boosted linguistic self-confidence. Whole-class discussions started to take up a lot more time, and sometimes students left the lesson still discussing the topic, sounding engaged. The rise in the number of active speakers suggests that some linguistic and non-linguistic barriers have been overcome due to a more relaxed environment which could, in fact, be felt.

\subsection{Student Interviews}

The analysis of the transcripts was carried out by finding the most commonly referred aspects in students' interviews. Generally speaking, students believe participation increased as there were more opportunities for all to speak. They also revealed a general feeling of more involvement and motivation to speak. On the whole, they sense a less stressful atmosphere, resulting in the release of some of the initial speaking anxiety. Most recognise they have overcome some linguistic barriers by experimenting language, content knowledge and lexis beforehand in the small groups. They feel they are more aware of communicative skills and more prepared for speaking outside the classroom and a fairly common example given is turn managing and floor holding. Overall, some alleged personality benefits are being less worried about mistakes, pronunciation and evaluation. 'Buzz-groups' seem to give students a sense of 'belonging', or 'membership.' and a shared responsibility before the whole-class, which has become a less intimidating audience.

\section{Conclusion}

It seems fair to conclude that it is possible to transform stressful communication into successful communication in whole-class discussions, thus increasing the number of participating students. The implementation of the two-step strategy has revealed that, when better informed and working in a less anxiety-inducing environment, 
learners can become active speakers. This seems to confirm that when students are using a foreign language they will perform better if they are under the least possible communicative stress (Brown and Yule 1983:34). It also seems beneficial to have collected the perspectives of all participants as there is a match between the benefits claimed by the teacher and the students. Overall, they are evidence that whole-class dynamics improved, this speaking activity became enjoyed by a greater number of students and a 'lighter' attitude made participation more 'wilful'.

Carrying out the discussions in the 'buzz groups' first, created a more relaxed and supportive learning environment among peers. Personal features such as shyness or embarrassment to speak in public were cushioned by the smaller group which functioned as a 'safety net'. These preparatory activities generated a greater bond between peers working towards a cooperative goal and becoming more involved in the task (Dornyei 1994). They worked like rehearsals with less 'others' to worry about and boosted individuals' self-confidence and motivation to speak. Several students managed longer turns, and held the floor long enough to express opinions. This confirms that taking turns in the format of the smaller group is less intimidating, as there is less risk of public embarrassment or failure than in front of an entire class (Murphy 1991).

The awareness- raising lessons also seemed to have had a positive effect in whole-class discussions, as fear of speaking in English in front of larger audiences seems minimised. Students interiorised the importance of becoming fluent and not worrying about making mistakes and claim feeling better prepared for encountering other non-native speakers. This study seems to demonstrate that it may be positive for EFL learners to learn about ELF, today's internationally acceptable English (Ur, 2009).

Although this is a qualitative study, teachers' notes show that there is a general increase in individual participation, that the number of regular participants rose, and more importantly, that there were several new participants. It is, therefore, possible to conclude that whole-class discussions became less-threatening with minimised speaking inhibition. The implemented 'buzz-groups' pre-activity became a desired procedure by this class for the following year.

The greatest limitation of this research was time. This study was carried out as part of a MSc' module with a deadline. This imposed the limit of 20 students and one class. With more time, transcripts of interviews could have been more intensely explored. As such, this is a qualitative study, these findings apply to this specific context and it is not possible to make generalisations. Initially, it was thought that the researcher would carry out her investigation inside a colleague's classroom allowing triangulation. This was not possible due to overlapping timetables. Having to work simultaneously as teacher and researcher, managing the activity and observing it, revealed quite challenging at times. Additionally, buzz-group discussions were noisy and difficult to monitor. Video-recording might have been an alternative research tool.

\section{Recommendations for Further Research}

My observations and hypothesis were mostly confirmed by the findings. The issues of speaking anxiety and raising learners' motivation are constantly on EFL teachers' list of concerns. It would be greatly beneficial to carry out further studies where both qualitative and quantitative analysis could be complementary. This would enhance the present study and yield more complete results that other practitioners might use.

\section{Acknowledgements}

I would like to thank my twenty enthusiastic students of the Degree of International Relations at ISCSP for their participation in this research.

\section{References}

Altricher, H., Posch, P., \& Somekh, B. (1993). Teachers investigate their work. London: Routledge.

Bailey, K. M., \& Nunan, D. (Eds.). (1996). Voices from the Language Classroom. Cambridge: Cambridge University Press.

Brown, H. D. (2000). Principles of Language Learning and Teaching. New York: Pearson Education.

Brown, G., \& G. Yule. (1983). Teaching the Spoken Language. Cambridge: Cambridge University Press.

Canagarajah, S. (2007). Lingua Franca English, Multilingual Commumities, and Language Acquisition. The Modern Language Journal, 91, Focus issue, 923-939. http://dx.doi.org/10.1111/j.1540-4781.2007.00678.x

Dewey, M. (2007). English as a lingua franca and globalization: an interconnect perspective. International Journal of Applied Linguistics, 17(3), 332-354. http://dx.doi.org/10.1111/j.1473-4192.2007.00177.x

Dornyei, Z. (1994). Motivation and Motivating in the Foreign Language Classroom. The Modern Language 
Journal, 78(3), 273-284. http://dx.doi.org/10.1111/j.1540-4781.1994.tb02042.x

Dornyei, Z. (1998). Motivation in second and foreign language learning. Language Teaching, 31(3), 117-135. http://dx.doi.org/10.1017/S026144480001315X

Dornyei, Z. (2001). Teaching and Researching Motivation. England: Pearson Education limited.

Ellis, R. (1986). Understanding Second Language Acquisition. Oxford: Oxford University Press.

Ellis, R. (1994). The Study of Second Language Acquisition. Oxford: Oxford University Press.

Ellis, R. (1997). Second Language Acquisition. Oxford: Oxford University Press.

Gnutzmann, C., \& F. Intermann. (eds) (2005). The globalization of English and the English language classroom. Tubingen: Gunther Narr.

Graddol, D. (1997). The Future of English? London: The British Council.

Graddol, D. (2006). English Next. London: The British Council.

Harmer, J. (2001). The Practice of English Language Teaching. Harlow: Longman/Pearson Education Limited.

House, J. (2003). English as a lingua franca: A threat to multilingualism? Journal of Sociolinguistics, 7(4), 556-578. http://dx.doi.org/10.1111/j.1467-9841.2003.00242.x

Hulmbauer, C., Bohringer, H., \& Seidlhofer, B. (2008). Introducing English as a Lingua Franca (ELF): Precursor and partner in international communication. Synergies Europe, 3, 25-36.

Jenkins, J. (2006a). Current Perspectives on Teaching World Englishes and English as a Lingua Franca. TESOL Quarterly, 40(1), 157-181. http://dx.doi.org/10.2307/40264515

Jenkins, J. (2006b). Points of view and blind spots: EFL and SLA. International Journal of Applied Linguistics 16(2), 137-162. http://dx.doi.org/10.1111/j.1473-4192.2006.00111.x

Jenkins, J. (2007). English as a Lingua Franca: attitude and Identity. Oxford: Oxford University Press.

Jenkins, J. (2009). World Englishes. New York: Routledge.

Johnson, K. E. (1995). Understanding Communication in Second Language Classrooms. Cambridge: Cambridge University Press.

Kachru, B. B. (1985). Standards, codification and sociolinguistic realism: the English language in the Outer circle. In R. Quirk, \& H. G. Widdowson (eds), English in the world. Cambridge: Cambridge University Press.

Krashen, S. (1981). Second Language Acquisition and Second Language Learning. Oxford: Pergamon.

Knap, K., \& C. Meierkord. (eds) (2002). Lingua franca communication. Frankfurt: Peter Lang.

Murphy, J. (1991). Oral Communication in TESOL: integrating speaking, listening and pronunciation. TESOL Quarterly, 25(1), 51-74. http://dx.doi.org/10.2307/3587028

Nunan, D. (1988). The Learner-centred Curriculum. Cambridge: Cambridge University Press.

Nunan, D. (1989). Designing tasks for the Communicative Classroom. Cambridge: Cambridge University Press.

Nunan D., \& Lamb C. (1996). The self-directed Teacher. Managing the learning process. Cambridge: Cambridge University Press.

Seidlhofer, B. (2001). Closing a conceptual gap: the case for a description of English as a lingua franca. International Journal of Applied Linguistics, 11(2), 133-158. http://dx.doi.org/10.1111/1473-4192.00011

Seidlhofer, B. (2002). The shape of things to come? Some basic questions about English as a lingua franca. In Knapp, K., \& Meierford, C. (Eds), Lingua franca communication (pp. 269-302). Frankfurt: Peter Lang.

Seidlhofer, B. (2004). Research perspectives on teaching English as a lingua franca. Annual Review of Applied Linguistics, 24, 209-39. http://dx.doi.org/10.1017/S0267190504000145

Seidlhofer, B. (2005). Key Concepts in ELT, English as a lingua franca. ELT Journal, 59(4), 339-341. http://dx.doi:org/10.1093/elt/ccio64

Seidhofer, B., \& J. Jenkins. (2003). English as a Lingua Franca and the Politics of Property. In Mair, C. (ed), The Politics of English as a World Language (pp. 139-154). Amsterdam: Rodopi.

Ur, P. (1981). Discussions that work (Part 1). Cambridge: Cambridge University Press. 
Ur, P. (1991). A Course in Language Teaching. Cambridge: Cambridge University Press.

Ur, P. (2009). English as a Lingua Franca and some implications for English teachers. Retrieved from http://www.tesol-france.org/Colloquim09/Ur_Plenary-Handouts.pdf

Williams, M., \& Burden, R. L. (1997). Psychology for Language Teachers. A social constructivist approach. Cambridge: Cambridge University Press.

Willis, J. (1996). A Framework for Task-based Learning. England: Longman.

\section{Appendix}

Excerpt commentaries from student interviews

How have 'whole-class discussions' changed for you?

1. I think it's easier for us to start talking in small groups because we have time to think about things and we have to give our opinion and discuss. One person says one word, and then another, it's easier, we remember and use vocabulary.

2. I now speak more in front of the class, first I was shy, every time that we speak in groups and then with the class, we begin to feel more comfortable. Things come out more naturally because we have already the vocabulary. It also helps you with the accent.

3. To discuss in groups and to change the people in the groups every time we do it is good for our English, it makes our English richer. This contact shows us different perspectives and pronunciation, so we know after.

4. I was afraid to speak with many people. With four people it's easier, I can give my opinion, I have a chance for ideas, it is like step by step.

5. I like to speak without being evaluated, we are free to fail, we can talk more time without thinking, oh I've made a mistake.

6. I have the impression that I speak more time this year than last year. I am more motivated by the little groups, I feel more confident.

7. Personally I don't talk much. I only talk when the issue, the subject is motivating. But when we work in small groups I am obliged to give my opinion because we are so few, then I get involved and give my view to the whole class.

8. I feel forced to speak when the teacher calls my name. I prefer to be a volunteer and when the subject is discussed in groups it interests me more, we feel we are learning with the others.

9. I think speaking in small groups it's easier than speaking in front of whole class, its main aim is fluency, it's easier to be fluent in small groups with people than I am in close contact, to have my ideas formed first within the group, then translate it to the whole class.

10. We can speak more regularly and become more fluent and also we can gain confidence when we are speaking in English with other people outside school, we share our points of view, our ideas and we improve our argumentative speech. 